\title{
RESEARCH IN MILKING INTERVALS ON PRACTICE FARM USING AUTOMATED MILKING SYSTEMS
}

\author{
Maris Rozentals, Armins Laurs, Juris Priekulis \\ Latvia University of Agriculture \\ armins.laurs@promedia.lv; juris.priekulis@1lu.lv
}

\begin{abstract}
The aim of the research is to state how the voluntary milking principle is implemented on the practice farm milking cows using automated milking systems (AMS). For the research the following tasks were set: to state the distribution and dispersion of the milking intervals as well as to determine the correlation between the yield per milking and the milking intervals. The research was performed on a good practice farm where 110 cows are milked with two DeLaval AMS. The selectively guided cow traffic to the AMS "first feeding, after milking" is used. The cows with milking permission but not milked yet are guided to the AMS in the morning and in the evening. Besides, a couple of times per day also the cows that are not milked, but for which milking is planned 3 to 4 times per day, are also guided to the AMS. The research was performed in 10 days with all 110 cows included. The input data necessary for the research were obtained from the AMS control system. pIt was stated in the research that the average yield per milking was $12.74 \mathrm{~kg}$, but the average number of milking times per day for the group of the cows - 2.6 times. Besides, such parameters milking with the AMS correspond to good practice indicators. It has been stated that in $13 \%$ of the cases of all milking times the milking intervals have been longer than 14 hours, but in $14.3 \%$ of the cases the cows have been milked more often than the set 6 hour interval. The average relative milking interval standard error for the whole group of the cows was $5.52 \%$, but the average correlation coefficient for the group of the cows between the yield per milking and the milking interval -0.24 .
\end{abstract}

Keywords: cow, milking robot, milking interval.

\section{Introduction}

Despite that the automated milking systems or the AMS are used for milking cows already for a long time, among practitioners and scientists there is still debate open about more rational solutions for guiding cows using automated milking. The topicality of this issue is related to the average quantity of the milk yield as with unreasonable increase of the length of the milking interval milk filling in the udder is retarded. Therefore, research in and practical solution of this issue is of economical importance.

The most rational ways of cow traffic to milking have been investigated by many scientists: Harms [1], Wall and MeFadden [2], as well as others [3-5], still, this problem is not researched enough. It is proved by our previous research [6;7], in which it has been stated that in practice the set milking intervals are not followed and in the result the average number of the milking times per day is reduced. But to eliminate this shortage participation of people in the process of milking is necessary to control the existing situation and if needed to guide the "lazy" cows for milking.

The aim of the research discussed in the present article is to state in detail how the voluntary milking principle milking cows with the AMS is implemented on a good practice farm where robotized milking equipment is used for already ten years and the milking regime has stabilized. Besides, the average productivity of the cows is approximately $11000 \mathrm{~kg}$ per year.

Considering the above mentioned the following tasks were set for the research:

- to state the distribution and dispersion of the milking intervals;

- to state the correlation between the yield per milking and the milking intervals.

\section{Materials and methods}

The research was performed in the milk cow barn of the training and research farm "Vecauce" of the Latvia University of Agriculture, where 500 cows are handled. Besides, 110 cows are milked by two AMS of the company DeLaval, but for other cows the parallel parlour $2 \times 10$ is used. On the mentioned farm the AMS was introduced in 2007. Therefore, long-time experience has been amassed there in application of the AMS. 
For guiding the cows to the AMS the technological solution "first feeding, after milking" is used. For this purpose in the AMS control system it has been set that the cows can get the milking permission for entering the robotic milking equipment according to the following criteria.

- Within the first 100 days after parturition the milking permission is given 6 hours after the previous milking or if the expected milk yield has reached $8 \mathrm{~kg}$ per one milking.

- During the further lactation period the milking permission is given 8 hours after the previous milking as well as if the yield per milking has reached $12 \mathrm{~kg}$.

The cow traffic to milking on the farm is controlled by a person - the cow mover, using the data of the management system for this purpose, having the duty to make out twice a day, i.e. in the morning and in the evening, which cows that have got the milking permission are not milked and to guide these cows to the AMS. Also, twice a day the cows that are not milked, but milking of which is planned 3 or 4 times per day, are guided to milking.

The research was performed in a 10 day interval and all 110 cows that are milked by the AMS were researched. Information on the procedure of milking the cows was obtained from the AMS control system and processed applying the corresponding software [8].

In the research the milking intervals as well as the corresponding milk yields for every cow were stated. Using these data the average relative standard error of the milking intervals, the average yield per milking as well as the correlation coefficient between the milking interval and the yield per milking were calculated. Additionally, also the average number of milking times per day was calculated.

The research results are presented in two graphs. One graph shows the frequency of every milking interval, the other - the diagram of couple correlation dispersion for the correlation between the milk yield and the milking interval.

\section{Results and discussion}

Pursuant to Table 1, it can be stated that during the period of the research the average yield per milking has been $12.74 \mathrm{~kg}$, but the average number of milking times - 2.6 times per day. Such indicators comply with the good practice indicators milking cows by the AMS $[1 ; 3]$.

Table 1

Indicators characterising the milking procedure

\begin{tabular}{|c|l|c|}
\hline No. & \multicolumn{1}{|c|}{ Indicators } & Characterising indicator \\
\hline 1. & Average yield per milking, kg & 12.74 \\
\hline 2. & $\begin{array}{l}\text { Average relative milking interval standard error for the group } \\
\text { of the cows }\end{array}$ & 5.52 \\
\hline 3. & $\begin{array}{l}\text { Average correlation coefficient between the milk yield and the } \\
\text { milking interval }\end{array}$ & 0.24 \\
\hline 4. & Average number of milking times per day & 2.60 \\
\hline
\end{tabular}

The percentual proportion of the cows, obtained in the research depending on the length of the milking intervals, is summarized in Figure 1.

The graph shows that only approximately in $13 \%$ of the cases calculating from all milking times the milking intervals have been longer than 13 hours. Besides, these cases are uniformly distributed among all cows. It means that only a small number of the cows have been milked less than two times per day. But in $14.3 \%$ cases the cows have been milked less frequently than the set 6 hour interval. It can be explained by the fact that after unsuccessful milking cases (incomplete milking, failed teat cup application to the cow's teat etc.) repeated milking permission is given automatically after less than 6 hours.

To characterize the milking procedure not only the distribution of the milking intervals according to their length but also the dispersion of these intervals are important. The less the dispersion, the more stable the process. Therefore, for every cow the average relative milking interval standard error was calculated, but after that - the average relative standard error for the whole group of the cows. As it is shown in Table 1, in our case this standard error is $5.52 \%$. Following the canons of the mathematical 
statistics [8] in cases when the result is $5-8 \%$, the relative standard error is satisfactory, although it is difficult to evaluate what it means in our case.

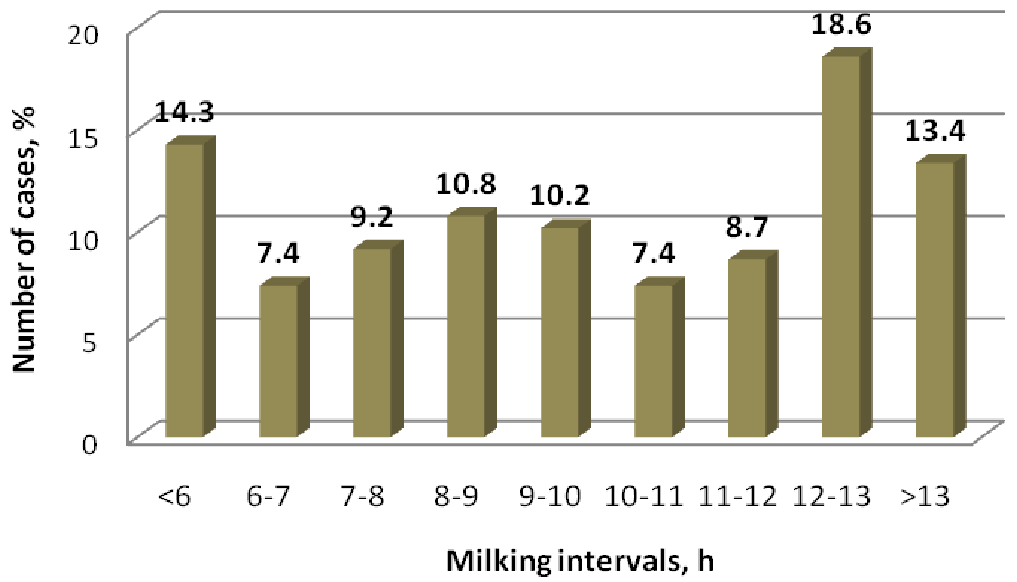

Fig. 1. Distribution of milking intervals

In turn, in the physiology of cow lactation an opinion exists that the milk yield should be proportional to the milking interval, but in our research considering the data about every milking time it is observed that this conclusion is not true. Therefore, the correlation coefficient between the milking interval and the yield per milking was calculated. At first it was calculated for every cow, afterwards it was determined as the average value for the whole group of the cows. The calculations show that the average correlation coefficient of the whole group of the cows between the milk yield and the milking interval was 0.24 , but according to the references of the mathematical statistics [8] the correlation is weak if the correlation coefficient is less than 0.5 .

The character of correlation can be determined from its dispersion diagram (see Fig. 2). This figure shows the couple correlation dispersion diagram for the correlation between the milk yield and the milking interval. From the diagram it can be concluded that there is such correlation between the milk yield and the milking interval, but it is comparatively weak [8] and positively linear.

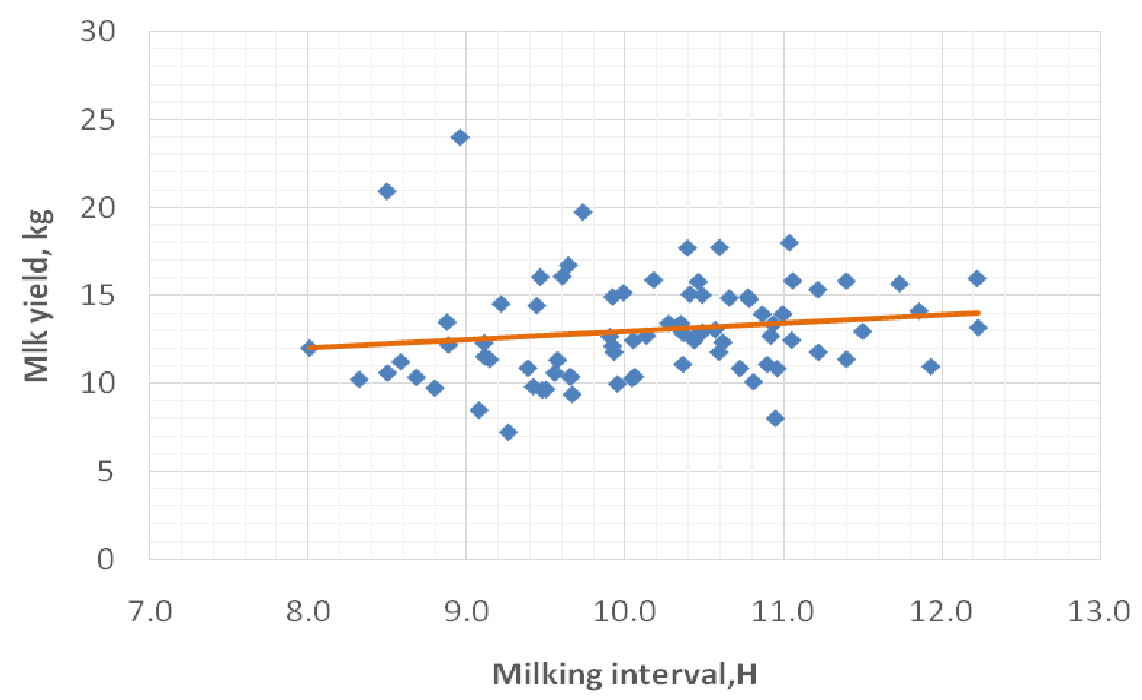

Fig. 2. Dispersion of milking intervals depending on the milk yield and correlation of these parameters

\section{Conclusions}

1. The farm, where the experiments were performed, is a good practice farm as the average productivity of the cows was $11000 \mathrm{~kg}$ per year, the average yield per milking exceeded $10 \mathrm{~kg}$ 
and every cow was milked on average 2.6 times per day. Besides, for milking of the cows included in the experiment the AMS was used.

2. On the farm the automatic setting of the milking permissions for the cows is practiced. Within the first 100 days of lactation the milking permission is given 6 hours after every milking or if the expected milk yield has reached $8 \mathrm{~kg}$ per one milking, but 100 days after lactation - 8 hours after the previous milking or if the expected yield per milking has reached $12 \mathrm{~kg}$. The cows having the milking permission but not milked are guided to the AMS by help of a person in the morning and in the evening. The cows that are not milked, but milking for which is planned 3 to 4 times per day, are also guided to the AMS.

3. Approximately $72 \%$ of all milking times take place with the milking interval $6-14$ hours, $14 \%$ less than 6 hours, but $13.4 \%$ longer than 14 hours. It means that only a few cows have been milked less than two times per day. Besides, in $14.3 \%$ of the cases the milking interval has been less than the set 5 hours. It can be explained by the fact that after unsuccessful milking cases (incomplete milking, failed teat cup application to the cow's teat etc.) repeated milking permission is given after less than 6 hours.

4. The average correlation coefficient for the group of the cows between the milk yield and the milking interval has been 0.24 and it means that this correlation is comparatively weak.

\section{References}

1. Harms J. H Untresuchungen zum Einsatz verschiedener Varianten des Tierumtriebs bei automatischen Melksystemen (Einboxanlage). Dissertation. Weihenstephan: Technischen Universität München, 2005. pp. 79-100.

2. Wall E. H., MeFadden T. B. Use it or lose it: Enhancing milk producion effeciecy by frequent milking of dairy cows. Journal of Animal Science 86 (suppl 1), 2008, pp. 27-36.

3. Artman R. Ergebnisse aus langjährigem Praxiseinsatz von Melkrobotern. In: Die 7. Internationale Tagung „Bau, Technik und Umwelt in der landwirtschaftlichen Nutztierhaltung 2005”. KTBL, Darmstadt,. 2005, pp. 145-150.

4. Hulsen J. Melken mit dem Roboter. Zutphen: Roodbont, 2008, p. 52.

5. Schön H. u.a. Automatische Melksysteme. KTBL: Darmstadt, 2000, pp. 95-96.

6. Laurs A., Priekulis J. Variability of milking frequency and intervals between milking in automatic milking systems. / Agronomy Research. No 9. (Special 1), Biosystems engineering. Saku :Rebellis, 2011. pp. 135.-141.

7. Лаурс А.Р., Приекулис Ю.К. Исследование динамики посещаемости доильных роботов коровами./ Материалы Международного агроэкологического форума. Том 3. 21-23 мая 2013 г., Санкт-Петербург. с. 27-33. (Research in Dynamics of Cows Entering Milking Robots)

8. Arhipova I., Bāliņa S. Statistika ekonomikā. Risinājumi ar SPSS un Microsoft Excel.Rīga: Datorzinību centrs.2003. 350 lpp. (Statistics in Economics, Solutions by SPSS and Microsoft Excel). 